DOI: 10.46340/ephd.2020.6.2.6

Vitaliya Gotynyan-Zhuravlyova, PhD in Philosophy

ORCID ID: https://orcid.org/0000-0003-0830-3893

Odesa I. I. Mechnikov National University, Ukraine

\title{
STANDARDLESS MEASUREMENT, CLASSIFICATION AND ARISTOTLE'S ONTOLOGY
}

\author{
Віталія Готинян-Журавльова, к. філос. н. \\ Одеський національний університет імені І.І. Мечникова, Україна
}

\section{БЕЗЕТАЛОННЕ ВИМІРЮВАННЯ, КЛАСИФІКАЦІЯ ТА ОНТОЛОГІЯ АРИСТОТЕЛЯ}

\begin{abstract}
There is no clear univocal definition of the method of standardless measurement in the modern scientific literature. Some methodologists of science believe that the concept of "classification" may be used in the definition of standardless measurement. Classification is one of the most common methods of cognition. Every science applies this method. What is classification? To answer this question, we should appeal to Aristotle's ontology of being. Moreover, the classification is methodologically and logically linked to the measurement procedure. The concept of classification is a generic term in the definition of standardless measurement. There is a definite connection between the ontological kinds of being according to Aristotle and types of standardless measurement. You can also find a mutual connection between the kinds of being according to Aristotle and the content of classification cells. So, is there any ontological relationship between such metods as classification and standardless measurement?
\end{abstract}

Keywords: classification, differentiation of concepts, sorting of things, Aristotle's ontology, essence, kinds of being, standardless measurement.

Вимірювання залишається одним з найпоширеніших методів, який використовується як в природничих, так і в суспільно-гуманітарних науках. 3 розвитком суспільно-гуманітарних наук та деяких напрямків природничих наук виявилося, що для вимірювання певних величин неможна використовувати еталонне вимірювання. Методологи звернулися до пошуку i використання альтернативних еталонному видів вимірювання, зокрема, до безеталонного вимірювання. Але в сучасній науковій літературі немає чіткого визначення безеталонного вимірювання. Перед методологами i логіками науки постає нове завдання: визначити поняття «безеталонне вимірювання». При визначенні поняття «вимірювання» як родове поняття часто використовується поняття «класифікація». Тому звернімося до аналізу методу класифікації і можливого онтологічного взаємозв'язку класифікації та безеталонного вимірювання.

Важко уявити сучасну розвинену науку, яка б не використовувала метод класифікації задля удосконалення і систематизації отриманих знань. Якщо для науки XIX століття класифікація була чимось особливим i надзвичайним, то наука XX i XXI століть не лише почала активно використовувати цей метод, а пред'являти свої вимоги щодо способів створення класифікації, визначення класифікації, чіткого розрізнення класифікації і класифікування, змісту класифікаційних чарунок.

Питання про зміст класифікаційних чарунок набуває особливого значення завдяки тому, що поняття «класифікація» є родовим поняттям при визначенні поняття «безеталонне вимірювання». Безеталонне вимірювання нами було визначено як класифікацію об'єктів, в ході якої з родового поняття вимірюваного об'єкту (до вимірювання) виокремлюються види за певною ознакою вимірюваною величиною або вимірюваною властивістю. Але подальшій аналіз цього визначення i подальше його уточнення привели до визначення поняття «безеталонне вимірювання» як виду вимірювання, де відбувається класифікація об'єктів за способом вимірювання, який може бути 
за зміною вимірюваної ознаки, наявністю-відсутностю вимірюваної ознаки або схожістюнесхожістю вимірюваної ознаки з умовним еталоном.

Слід підкреслити, що крім логічного, гносеологічного і методологічного видів аналізу існують і онтологічні питання, пов'язані з природою об'єктів, що класифікуються. Виникає питання: чим насправді є елементи, які містяться у класифікаційних чарунках - ідеальними конструкціями (тобто поняттями) або фрагментами матеріального світу (реальними об'єктами)?

3 онтологічної точки зору, зокрема, спираючись на онтологію Аристотеля, зміст класифікаційних чарунок буде другою сутністю або четвертим сущим, якщо класифікаційні чарунки наповнюються ідеальними конструкціями, або ж першою сутністю або третім сущим, якщо класифікаційні чарунки наповнюються фрагментами матеріального світу. Тому іншою важливою і цікавою з онтологічної точки зору темою щодо обговорення проблем класифікації $є$ питання: чим насправді є класифікація - поділом понять або сортуванням речей.

Думки провідних філософів і методологів науки різняться щодо того, чим $є$ класифікація. Так перша точка зору полягає в тому, щоб як класифікацію слід розуміти багаторівневий поділ родового поняття на види за певними ознаками. Такої точки зору дотримуються такі провідні вітчизняні та закордоні логіки і методологи науки як О. Д. Гетманова, І. В. Хоменко, М. Г. Тофтул, В. П. Плавич, Є. А. Іванов, А. І. Уйомов. Отже, і класифікаційні чарунки повинні містити у собі ідеальні конструкції, поняття про речі. Інші автори, такі як Г. І. Челпанов, М. І. Кондаков, А. Л. Суботін, А. Є. Конверський, С. М. Повторева розуміють класифікацію як розподіл множини досліджуваних предметів певного роду на класи відповідно до найбільш суттєвих ознак. В цьому випадку класифікаційні чарунки будуть містити у собі реальні речі, досліджувані об'єкти.

Оскільки, як зазначалося раніше, поняття «класифікація»є найближчим родовим поняттям при визначенні поняття «безеталонне вимірювання», а безеталонно вимірюються як матеріальні речі, які неможна вимірити за допомогою еталону, так і ідеальні речі, тому проблема змісту класифікаційних чарунок тісно пов'язана із механізмами безеталонного вимірювання.

Раніше нами було розглянуто взаємозв'язок існуючих думок щодо того як пов'язана класифікація з видами буття за Аристотелем ${ }^{1}$. В інший роботі розглянуті онтологічні аспекти безеталонного вимірювання, тобто взаємозв'язок видів безеталонного вимірювання і видів буття за Аристотелем².

Тому метою даної статті $€$ пошук певного онтологічного взаємозв'язку між методом класифікації і методом безеталонного вимірювання, оскільки існують взаємозв'язки між видами буття за Аристотелем і видами безеталонного вимірювання та видами буття за Аристотелем i змістом класифікаційних чарунок.

В онтології Аристотеля центральним поняттям є категорія сутності: «Якби не існувало перших сутностей, не могло б існувати нічого іншого» ${ }^{3}$. В «Категоріях» Аристотель виділяє дві ознаки, два параметра, за якими поділяє буття: знаходиться упідлягаючому і позначатися про підлягаюче. Знаходитися у підлягаючому може все те, «що не $є$ частиною, не може існувати окремо від того, у чому воно знаходиться» ${ }^{4}$. Наприклад, знаходяться у підлягаючому різні якості предметів - розумний, яскравий, істинний... Позначатися про підлягаюче може все те, що можна приписати йому як властивість. Наприклад, предикат в простому категоричному суджені можна приписати всьому або частині суб'єкта. Тому предикат позначається про підлягаюче, про суб'єкт. Аристотель дихотомічно поділяє кожну ознаку на два види: знаходиться у підлягаючому та не знаходиться у підлягаючому, позначається про підлягаюче та не позначається про підлягаюче. Далі він комбінує ці ознаки: «Із всього існуючого одне позначається про будь-яке підлягаюче, але не знаходиться ні в якому підлягаючому, наприклад, людина; про підлягаюче - окрему людину говориться як про людину, але людина не знаходиться ні в якому підлягаючому; інше знаходиться у підлягаючому, але не позначається ні про яке підлягаюче...; наприклад, певне уміння читати i писати знаходиться ${ }^{5}$ у підлягаючому - в-душі, але ні про яке підлягаюче не говориться як про певне

\footnotetext{
${ }^{1}$ Готинян-Журавльова, В. (2012). Онтологические аспекті класификации. Ученые записки Таврического университета им. В.И. Вернадского. Научный журнал. Серия: Философия. Культурология. Политология. Социология, 4, 333-338.

2 Готинян-Журавльова, В. (2005). Логико-системніе аспекті проблемі измерения. Одеса: ОНУ.

${ }^{4}$ Аристотель (1978). Категории. Москва: Мысль, 2в, 6-7.

${ }^{5}$ Аристотель (1978). Категории. Москва: Мысль, 1а, 20-25.
} 
уміння читати і писати. І певне біле знаходиться у підлягаючому - у тілі (тому що будь-який колір у тілі), але ні про яке підлягаюче не позначається як про певне біле. А інше і позначається про підлягаюче, i знаходиться в підлягаючому - у душі - i про підлягаюче - уміння читати і писати позначається як про знання. Нарешті, інше не знаходиться у підлягаючому і не позначається про будь-яке підлягаюче, наприклад, окрема людина й окремий кінь» ${ }^{1}$. Таким чином, Аристотелем бути виділені чотири категорії буття: 1-а сутність, 2-а сутність, 3-е суще, 4-е суще, котрі як запропонував ак. А. І. Уйомов можна представити у вигляді таблиці².

Таблиця 1

\section{Таблиця сутностей і сущого}

\begin{tabular}{|c|c|c|}
\hline Сутності & $\begin{array}{c}\text { Знаходиться } \\
\text { у підлягаючому }\end{array}$ & $\begin{array}{l}\text { Позначається про } \\
\text { підлягаюче }\end{array}$ \\
\hline 1-а сутність & ні знаходиться & Не позначається \\
\hline 2-а сутність & ні знаходиться & позначається \\
\hline 3-е суще & знаходиться & Не позначається \\
\hline 4-е суще & знаходиться & позначається \\
\hline
\end{tabular}

Перша сутність має наступну комбінацію: «не знаходиться ні в якому підлягаючому» і «не позначається ні про яке підлягаюче». До першої сутності Аристотель відносить: «вочевидь всього, як думають, сутність властива тілам; тому ми називаємо сутностями тварин, рослини і їхні частини, а так само природні тіла такі, як вогонь, вода і земля і кожне тіло цього роду, а також усе те, що є частиною їх чи складається з них - або з їхніх частин, або з усієї сукупності їхній, - наприклад, небо і його частини, Місяць і Сонце» ${ }^{3}$.

Другі сутності не знаходяться ні в якому підлягаючому тобто існують окремо, але можуть позначатися про підлягаюче. До других сутностей не можна віднести окремі предмети, які можна вказати за допомогою знаків чи імен, бо ці сутності позначаються про підлягаюче. Другі сутності - це сутності, які стосовно предметів будуть тим, що в логіці має назву рід чи вид. «Що стосується других сутностей,- зазначає Аристотель,- то про підлягаюче позначається і їх визначення, i їх ім'я: адже визначення людини стосується до окремої людини і визначення живої істоти - точно також» ${ }^{4}$.

Трете суще «знаходиться у підлягаючому», але «не позначається ні про яке підлягаюче». Оскільки знаходиться у підлягаючому, то неможна назвати сутністю, бо сутність - це усе те, що має самостійне існування. Це здатність читати і писати, що знаходяться в душі людини; це синява, що властива тільки серпневому небу. Відокремити ознаку третього сущого, наприклад, від душі (якщо вона знаходиться в душі) неможливо.

Четверте суще «знаходиться у підлягаючому», «позначається про підлягаюче». Жодна 3 цих властивостей не існує від природи сама по собі і не може відокремлюватися від предмету. Це властивості, що виявляються не в окремому об'єкті, а в цілому ряді класів чи об'єктів. Це здатність читати і писати, яка знаходиться в душі кожної людини, це синява, яка властива небу, це вміння пекти пиріжки, це вміння співати, тощо.

Звернімося до визначення поняття «класифікація» і пригадаємо що до цього часу логіки i методологи науки не відповіли на питання: чим насправді $є$ класифікація - багаторівневим поділом поняття чи сортуванням речей? А звідси випливають інші питання: що повинні містити у собі класифікаційні чарунки - видові поняття або реальні речі; як може вплинути багатозначність терміну «класифікація» на онтологічний «зміст» класифікаційних чарунок та інші питання.

\footnotetext{
${ }^{1}$ Аристотель (1978). Категории. Москва: Мысль, 1а, 20-25; 1в, 5.

2 Уёмов, А. (2010). Метафизика: учебное пособие. Одесса: Астропринт.

${ }_{3}^{3}$ Аристотель (1976). Метафизика. Москва: Мысль, 1028а, 8-14.

${ }^{4}$ Аристотель (1978). Категории. Москва: Мысль, 3а, 15-20.
} 
Розуміючи класифікацію як сортування речей, в рамках онтологічних уявлень Аристотеля, ми аналізуємо перші сутності - окремі речі і їх частини. Основним принципом цього процесу $є$ порівняння об'єктів, що розглядаються, з заданими зразками, так званими еталонними представниками класів. Якщо ми пригадаємо, що способів створення класифікації може бути два: дедуктивний та індуктивний, то нашому випадку відповідає саме індуктивний спосіб створення класифікації, при якому аналізуються окремі об’єкти, що об'єднуються у класи, на основі подібності або відмінності ознак.

Розуміючи класифікацію як поділ понять, в рамках онтології буття Аристотеля, ми аналізуємо роди, виокремлюємо 3 них види за певними правилами, тобто аналізуємо другі сутності. При цьому ми не наповнюємо класифікаційні чарунки реальними об'єктами - зоряними сузір'ями чи різновидами мінералів, чи гірськими породами. В даному випадку вчених цікавлять питання аналізу понять, дедуктивного аналізу понять. Пригадаємо, що при дедуктивному створені класифікації «оперують з поняттями і на основі подібностей або відмінностей їх ознак встановлюють між ними родо-видове відношення» ${ }^{1}$.

Аналіз змісту поняття «класифікація» вказує на те, що найчастіше це поняття використовується, принаймні, в двох значеннях: як найменування вже створеної класифікації і як позначення процесу iї створення, побудови. Найчастіше для позначення вже існуючої класифікації використовується термін «класифікація», а для позначення процесу створення термін «класифікування».

Як зазначає I. Я. Чупахін: «призначення будь-якої класифікації в науках міститься в тому, щоб бути засобом найкращого пізнання об'єктів, що вивчаються, про які до класифікації ще не було сформовано понять» ${ }^{2}$. Більшість задач, які виникають перед нами в процесі нашого дослідження, вимагають застосування вже існуючих класифікацій, існуючих в певних галузях знання, а, значить, і існуючих у підлягаючому - в цих галузях знання. А це означає, що створені класифікації належать до третього або четвертого сущого залежно від їх загального застосування. Крім того, якщо створення класифікації відбувалося індуктивним шляхом, то вона базується на сортуванні речей i, імовірніше, належить до третього сущого, яке знаходиться у підлягаючому, але не позначається про нього. Якщо створення класифікації відбувалося дедуктивним шляхом, тобто шляхом поділу понять, то, імовірніше, створена класифікація належить до четвертого сущого, яке і знаходиться у підлягаючому (у певній галузі знання) і позначається про нього, бо «про підлягаюче позначається і їх визначення, і їх ім'я»³.

Проаналізуємо взаємозв'язки видів безеталонного вимірювання і видів буття за Аристотелем. Ретельний аналіз цього питання був проведений в роботі ${ }^{4}$.

На наш погляд, об'єкти вимірювання, які слід віднести до перших сутностей, тобто реальні речі і їх частини, вимірюються за допомогою еталонного вимірювання або, у при неможливості вимірити еталонно, тим видом безеталонного вимірювання, яке засновано на порівнянні двох речей $(\mathrm{m} 1, \mathrm{~m} 2)$, одна з яких виступає в якості деякого «умовного» еталона для порівняння (m1), а інша є об'єктом вимірювання (m2) - R(m1, m2). Імовірно, для якісного вимірювання тілесних (просторових) одиничних об'єктів, найбільше підходить саме даний вид безеталонного вимірювання. Пригадаємо один із прикладів цього виду безеталонного вимірювання, а саме вимірювання твердості мінералів за шкалою Мооса. 3 погляду онтології, у даному випадку відбувається порівняння двох одиничних об'єктів - двох перших сутностей. Якщо мінерал, твердість якого треба вимірити, залишає подряпину на квазіеталоні, то його твердість більше за твердість квазіеталона. Якщо квазіеталон залишає подряпину на вимірюваному об'єкті, то його твердість менше за твердість квазіеталона. Якщо вимірюваний об'єкт залишає подряпину на квазіеталоні i квазіеталон може залишити подряпину на вимірюваному зразку, то твердості квазіеталона й об'єкта вимірювання збігаються. В усіх розглянутих ситуаціях операції порівняння піддавалися два конкретних мінерали, два одиничних об’єкта, що є першими сутностями. Пригадаємо також приклад з нормативно-орієнтовними тестами, завданням яких $є$ не лише оцінювання знань учнів, a ïх

\footnotetext{
${ }^{1}$ Розова, С. (1986). Классификационная проблема в современной науке. Новосибирск: Наука, 12.

${ }^{2}$ Цит. за Розова, С. (1986). Классификационная проблема в современной науке. Новосибирск: Наука, 12.

${ }_{3}^{3}$ Аристотель (1978). Категории. Москва: Мысль, 3а, 15-20.

${ }^{4}$ Готинян-Журавльова, В. (2005). Логико-системніе аспекті проблемі измерения. Одеса: ОНУ.
} 
оцінювання і аналіз задля створення рейтингу учнів. Отже знову відбувається порівняння перших сутностей - конкретних учнів.

Об'єкти вимірювання, які слід віднести до других сутностей, на наш погляд, виміряються за допомогою виду безеталонного вимірювання, заснованого на комбінації ознак, властивостей вимірюваного об'єкта: $\mathbf{R}\left(\mathbf{R}_{\mathbf{1}}, \mathbf{R}_{\mathbf{2}}, \ldots\right)$. Звернімося до прикладу. Не залежно від расової приналежності, віку, статті, будь-яких інших ознак у людини може бути одна з чотирьох груп крові, які визначаються комбінацією ізоантигенів А, В та ізоантитіл $\alpha$ і $\beta$ з урахуванням певних умов, а саме, що разом у крові можуть знаходитися тільки різнорідні ізоантигени та ізоантитіла (наприклад, ізоантиген А та ізоантітіло $\beta$ або ж ізоантиген В та ізоантітіло $\alpha$ ). Завдяки комбінації цих параметрівз урахуванням зазначеної умови, виокремлюють чотири групи крові: O $\alpha \beta$ (I), A $\beta(\mathrm{II})$, $\mathrm{B} \alpha(\mathrm{III}), \mathrm{AB}(\mathrm{IV})$. Однак слід підкреслити, що комбінацією параметрів вимірюється група крові не лише конкретної людини. Кожна з чотирьох комбінацій параметрів визначає, так би мовити, вид людей, яким належить деяка властивість - мати певну групу крові. Відповідно до онтології Аристотеля, за допомогою даного виду безеталонного вимірювання ми вимірили другі сутності.

Пригадаємо й інший приклад цього виду безеталонного вимірювання, а саме, досліди по моногібридному схрещуванню рослин, які проводив Георг Мендель. Моногибрідне схрещування - це схрещуванню двох організмів, які відрізняються один від одного за однією парою ознак. При такому схрещуванні просліджуються закономірності спадкування тільки двох ознак, розвиток яких обумовлений парою алельних генів. Всі інші ознаки до уваги не беруться. В результаті у гібридів першого покоління з кожної пари альтернативних ознак розвивається тільки одна, так звана, домінантна ознака, а рецесивна ознака не виявляється. Якщо нащадків першого покоління, які є однаковими за досліджуваною ознакою, схрестити між собою, то в другому поколінні ознаки обох батьків виявляються у визначеному числовому співвідношенні: $3 / 4$ особин будуть мати домінантну ознаку, $1 / 4$ частина особин будуть мати рецесивну ознаку. Так відповідно до третього закону Г. Менделя комбінація генів особин, які схрещуються, повністю описує і вимірює наступне покоління. І тут мова йде не про конкретні особини першого, другого і подальших поколінь. Закон Г. Менделя стосується цілої низки особин, тобто того, що, за Аристотелем, слід віднести до других сутностей.

Об’єкти вимірювання, які слід віднести до третього сущого, вимірюються за допомогою виду безеталонного вимірювання, яке засновано на зіставленні (порівнянні) ознаки $\left(\mathrm{P}_{1}\right)$, властивої вимірюваної речі $(\mathrm{m})$ з ознакою $\left(\mathrm{P}_{2}\right)$, що представляє деякий «умовний» еталон вимірювання: $\mathbf{R}\left[(\mathbf{m} *) \mathbf{P}_{1}, \mathbf{P}_{2}\right]$ Прикладом даного виду безеталонного вимірювання може бути оцінювання знань учня з певної змістовної області, тобто оцінювання обсягу знань, які повинні бути засвоєні учнем протягом відповідного терміну навчання. В даному прикладі об'єктом дослідження (m) виступає учень, а безеталонно вимірюються знання учня за визначеною дисципліною $\left(\mathrm{P}_{1}\right)$. Знання, відповідно до представлень Аристотеля, є третім сущім тому що знаходяться в підлягаючому у нашому випадку «в учні». Позначатися вимірювані знання будуть не про «рід чи вид» учнів, а про конкретного учня. Нагадаємо, що механізм даного виду безеталонного вимірювання полягає в зіставленні вимірюваної властивості $\mathrm{P}_{1}$ із властивістю $\mathrm{P}_{2}$, що узята в якості деякого умовного квазіеталону. В розглянутому прикладі квазіеталоном $\epsilon$ перелік того, що повинен знати і вміти учень по даному предмету, щоб його знання оцінювалися відповідним балом. Перелік являє собою сукупність деяких властивостей. Однак, всупереч онтології Аристотеля, ці властивості розглядаються окремо від об’єкта, якому вони належать.

Пригадаємо інший приклад даного виду безеталонного вимірювання, в якому йшлося про вимірювання висоти хвиль за шкалою адмірала Дугласа. Так висота хвиль $\left(\mathrm{P}_{1}\right)$, яку вимірювали моряки в даному конкретному випадку, при хвилюванні моря чи океану, була вимірюваною властивістю, яка належала конкретному вимірюваному об'єкту (m). В результаті вимірювання відбувалося порівняння з ознаками хвилювання моря чи океану, які спостерігав і занотував адмірал Дуглас $\left(\mathrm{P}_{2}\right)$, визначаючи ступінь хвилювання і приблизну висоту хвилі. Якщо знаходили збіг, то позначали хвилювання певною назвою і певним балом. При цьому відбувалося порівняння ознак, які належали конкретним речам, тобто порівнювалися те, що в онтології має назву третє суще.

Нарешті, об'єкти вимірювання, що є четвертим сущим, вимірюються за допомогою виду безеталонного вимірювання, заснованого на зіставленні ознаки (Р) з вимірюваною річчю $(\mathrm{m})-\mathbf{R}(\mathbf{P}, \mathbf{m})$. Результатом даного виду безеталонного вимірювання $є$ відповідь на питання: чи 
належить розглянута ознака (Р) вимірюваній речі (m)? При цьому можливі ситуації, за яких досліджувана ознака належить не тільки даному конкретному об'єкту, а цілому ряду іншим об'єктів, які є схожими $з$ тим, що розглядається. Розглянемо приклад з вимірюванням вірусних гепатитів. Вірусні гепатити можуть бути розділені на два види: інфекційні і сироваткові гепатити. Якщо вимірюваному гепатиту (відповідно до наших позначень $\mathrm{m}$ ) відповідає контактний механізм зараження, також групова захворюваність з формуванням епідемічних вогнищ, то вимірюваний гепатит відноситься до класу інфекційних чи епідемічних гепатитів. Однак слід уточнити, що до цього класу відносяться, принаймні, два види гепатитів, так звані гепатит А та гепатит Е. Для більш докладного опису вимірюваної речі необхідно подальше уточнення продовження процедури безеталонного вимірювання, але вже з іншою ознакою (Р'). Таким чином, можна висловити припущення, що розглянутим видом безеталонного вимірювання легше виміряються властивості, які належать цілим класам об'єктів, ніж одиничним об'єктам.

Пригадаємо інший приклад, а саме операцію кодування, яку, деякі методологи науки відносять до процесу вимірювання тому що при кодуванні відбувається процес приписування значенням змінної певного коду, або шифру чи будь-яких інших показників, умовних позначок за певними правилами. Найчастіше буває так, що властивість, яка цікавить дослідника, якісно повністю не $є$ визначеною і вона аналізується як крапкова властивість. При таких вимірюваннях відбувається фіксація, констатація наявності або відсутності у певних об'єктів (або об'єкту - m) вимірюваної ознаки (Р), тобто відбувається безеталонне вимірювання. При цьому властивість, яка приписується об'єкту вимірювання, не $є$ лише його властивістю, не $\epsilon$ третім сущім. Вона належить певній кількості об’єктів і, з точки зору онтології Аристотеля, є четвертим сущім.

Отже ми розглянули взаємозв'язок між природою об'єкта, властивості або властивість якого вимірюється, з видами безеталонного вимірювання, які найкраще застосовувати саме цього об'єкту. Підкреслимо, що найкраще застосовувати, а не лише застосовувати тільки цей механізм вимірювання.

Відповідно усьому вище викладеному, можна доповнити таблицю сутностей, яку ми розглядали вище, четвертим стовпчиком, а саме видами безеталонного вимірювання. Але пригадаємо, що об'єкти, які можна віднести до перших сутностей, піддаються так само й еталонному вимірюванню.

Таблиця 2

Взаємозв'язок видів буття та видів безеталонного вимірювання

\begin{tabular}{|c|c|c|c|}
\hline Сутність & $\begin{array}{c}\text { Знаходиться } \\
\text { у підлягаючому }\end{array}$ & $\begin{array}{c}\text { Позначається про } \\
\text { підлягаюче }\end{array}$ & $\begin{array}{c}\text { Види безеталонного } \\
\text { вимірювання }\end{array}$ \\
\hline 1-а сутність & не знаходиться & не позначається & $\mathrm{R}\left(\mathrm{m}_{1}, \mathrm{~m}_{2}\right)$ \\
\hline 2-а сутність & не знаходиться & Позначається & $\mathrm{R}\left(\mathrm{P}_{1}, \mathrm{P}_{2}, \ldots\right)$ \\
\hline 3-е суще & знаходиться & не позначається & $\mathrm{R}\left[(\mathrm{m} *) \mathrm{P}_{1}, \mathrm{P}_{2}\right]$ \\
\hline 4-е суще & знаходиться & Позначається & $\mathrm{R}(\mathrm{P}, \mathrm{m})$ \\
\hline
\end{tabular}

Таким чином, нами було виявлено певні онтологічні закономірності щодо взаємозв'язку понять «класифікація» та «безеталонне вимірювання». Пригадаємо, що цей взаємозв'язок встановлюється задля найбільш вдалого визначення поняття «безеталонне вимірювання» в загалі і визначення кожного з видів безеталонного вимірювання окремо.

Якщо предметом нашого дослідження є об'єкти, які слід віднести до перших сутностей, а до них належать окремі об'єкти i їх частини, то зазвичай перші сутності вимірюються за допомогою еталонного вимірювання, або ж виду безеталонного вимірювання, який засновано на порівнянні двох об’єктів - вимірюваного об'єкту і квазіеталону $\left(\mathrm{R}\left(\mathrm{m}_{1}, \mathrm{~m}_{2}\right)\right)$. Якщо нашим завданням буде класифікувати перші сутності, то найчастіше вони будуть класифікуються за допомогою процедури сортування речей. Вимірюючи певний матеріальний об'єкт за допомогою еталону, або ж квазіеталону, ми визначаємо його певне місце в класифікації і вимірюваний об'єкт займає це місце. На нашу думку, на цей факт слід звернути увагу при визначенні даного виду безеталонного вимірювання, оскільки при визначенні як родове поняття 
може бути використано поняття «класифікування». Зазначимо, що в даному випадку класифікування відбувається переважно індуктивним шляхом.

Якщо в процесі нашого дослідження необхідно вимірити об'єкт або об'єкти, які можна віднести до других сутностей, а до них належать не окремі об'єкти, а ідеальні конструкції - те, що в логіці має назву «роди, види», то вимірюватися вони будуть за допомогою виду безеталонного вимірювання, заснованого на комбінації суттєвих ознак вимірюваного об'єкту $\left(\mathrm{R}\left(\mathrm{R}_{1}, \mathrm{R}_{2}, \ldots\right)\right)$. Класифікуватися об'єкти, які належать до других сутностей, будуть за допомогою логічної операції поділу понять, причому класифікація ця буде створюватися суто дедуктивним шляхом. Тобто при визначенні даного виду безеталонного вимірювання як родове поняття можна використовувати поняття «класифікація».

Об’єкти, які слід віднести до третього сущого, зазвичай вимірюються за допомогою виду безеталонного вимірювання, який засновано на порівняні ознаки, що належить вимірюваному об'єкту, з іншою ознакою, прийнятою за умовно обраний квазіеталон вимірюваної величини $\left(\mathrm{R}\left[(\mathrm{m} *) \mathrm{P}_{1}, \mathrm{P}_{2}\right]\right)$. Вимірюється ознака, яка належить об'єкту дослідження, і це підкреслюється навіть в позначені даного виду вимірювання $\left((\mathrm{m} *) \mathrm{P}_{1}\right)$, а отже можна вважати, що дослідник працює з третім сущим. При цьому дослідник, коли відносить виміряну ознаку до певного класу, найчастіше створює індуктивним шляхом класифікацію. В даному випадку, родовим поняттям для виду безеталонного вимірювання, що позначається як $\mathrm{R}\left[(\mathrm{m} *) \mathrm{P}_{1}, \mathrm{P}_{2}\right]$, може бути поняття «класифікація».

Об’єкти вимірювання, які можна віднести до четвертого сущого, а це ознаки, властивості, які належать не одному об'єкту, а цілій низці об'єктів, вимірюються за допомогою виду безеталонного вимірювання, який засновано на зіставлені ознаки з вимірюваною річчю $(\mathrm{R}(\mathrm{P}, \mathrm{m}))$. Дослідник вимірює певний об'єкт маючи певний набір ознак, які є суттєвими в рамках його дослідження і можуть належати або не належати вимірюваному об'єкту. При цьому дослідник фіксує: чи належить ознака, яка цікавить дослідника, вимірюваному об'єкту, чи не належить. Він знаходить певне, найбільш вдале, місце у вже існуючій класифікації для вимірюваного об'єкту. А для цього необхідно мати ці «еталонні» ознаки. На наш погляд, це стає можливим лише за наявності вже існуючого усталеного набору ознак, або ж вже існуючої усталеної класифікації, створення якої відбувалося дедуктивним шляхом. I відповідно це поняття «усталена класифікація, яка створена дедуктивним шляхом» може бути родовим поняттям при визначені виду безеталонного вимірювання, що позначається як $\mathrm{R}(\mathrm{P}, \mathrm{m})$.

Безеталонне вимірювання продовжує бути одним знайактуальнішим альтернативних еталонному методів вимірювання. Але в сучасній науковій літературі немає чіткого визначення безеталонного вимірювання. Аналізуючи визначення поняття «вимірювання» ми виокремлюємо групу визначень, в яких родовим поняттям $\epsilon$ поняття «класифікація». Але аналізуючи саме поняття «класифікація» ми зіштовхуємося з цілою низкою питань, зокрема, чим є класифікація: поділом понять або сортуванням речей. Тому тема, яка пов'язана з питаннями механізму класифікації, змістом класифікаційних чарунок, потребує подальшого ретельного аналізу, причому аналізу не лише логічного, а й онтологічного, адже, цікавим є той факт, що поняття «класифікація» при різних умовах може належати до різних видів буття. А різні види буття вимірюються за допомогою різних видів вимірювання. На нашу думку, саме цей факт може допомогти у визначенні безеталонного вимірювання.

\section{References:}

1. Gotynyan-Zhuravlova, V. (2012). Ontolohichni aspekty klasyfikatsii [The ontological aspects of classification]. Uchjonye zapiski Tavricheskogo nacionalnogo universiteta im. V. I. Vernadskogo. Nauchnyj zhurnal. Serija:

Filosofija. Kulturologija. Politologija. Sociologija [The scientific notes of the Taurida National University named after V. Vernadsky. Science Magazine. Series: Philosophy. Culturology. Political science. Sociology], 4, 333-338. [in Ukrainian].

2. Gotynyan-Zhuravlova, V. (2005). Lohiko-systemni aspekty problemy vymiriuvannia [The logical and systems aspects of the problem of measurement]. Odesa: ONU. [In Ukrainian].

3. Aristotel (1978). Kategorii [Category]. Moscow: Mysl. [in Russian].

4. Ujomov, A. (2010). Metafizika: uchebnoe posobie [Metaphysics: study guide]. Odesa: Astroprint. [in Russian].

5. Aristotel (1976). Metafizika [Metaphysics]. Moscow: Mysl. [in Russian].

6. Rozova, S. (1986). Klassifikacionnaja problema v sovremennoj nauke [The classification problem in the modern science]. Novosibirsk: Nauka. [in Russian]. 